\title{
Physicochemical and Technological Studies on Husk Tomato (Physalis pruinose L.)
}

\author{
Abou-Farrag, H.T., Abdel-Nabey, A.A., Abou-Gharbia, H.A. \& Osman, H.O.A ${ }^{1}$
}

\begin{abstract}
Physicochemical properties, nutritive value and ability to processing of husk tomato (Physalis pruinosa $\mathrm{L}$.) "local variety" were carried out. The influence of drying conditions such as pretreatments and drying methods and its effects on acceptability, quality, physicochemical properties and storage stability of the dried product and their application in some food products were also undertaken. The results indicated that combining hot air with microwave drying reduced the drying time by about $35 \%$. The moisture content and the total amount of titratable acidity increased after drying and storage. On the other hand, ascorbic acid content, phenolic compounds, total antioxidant activity, total and free sulphur dioxide content decreased after drying and storage for the different periods at room temperature. Dried husk tomato no longer had any microbial growth and can inhibit the spread of fungi and bacteria. The organoleptic properties of cake containing dried husk tomato and chocolate coated husk tomato were accepted by the panelists with some suggestions.
\end{abstract}

Keywords: Husk tomato, physical and chemical properties, pretreatments and drying, technological utilization

\section{INTRODUCTION}

Many beneficial plant species have been underused or have not been developed to their full potential such as husk tomato. Useful plant species have often been overlooked because they are native to the tropics which are regions neglected by the world's research institutions. (Vietmeyer, 1986). Solanaceae is mainly a tropical family of about 75 genera and 2000 species. The genus Physalis of family Solanaceae, contains about 100 species of annual and perennial herbs (Rubatzky and Yamaguchi, 1997 \& Willis, 1966). Generally, goldenberries or husk tomato fruits (Physalis pruinosa L.) are eaten fresh. Sometimes they are sweetened by pricking the skin and rolling them in sugar, which they absorb. Also, goldenberries or husk tomatoes are used in sauces and glazes for meat and seafood. The processed fruits are commonly used in preserves such as jams and jellies. Goldenberries are canned whole in syrup and they form what has been called 'a very agreeable raisin', besides, goldenberries are added as an intriguing flavour to desserts. (Popenoe, 1989). Small industries are developed around the husk

\footnotetext{
${ }^{1}$ Food Science and Technology Dept., Fac. of. Agric., El-Shatby, Alexandria Univ., 21545, Alexandria, Egypt Received April 3, 2013, Accepted June18, 2013
}

tomato in some countries but nowhere has it really achieved large commercial success. The plant's productivity in poor soil, its ease of cultivation and low requirement for water and fertilizer has made it an attractive potential crop (Morton, 1987). In Egypt, the cultivation, production, consumption and utilization of goldenberry are given no attention. Fruits are perishable (due to its high moisture content) having a short marketing season. Although, the fruit has a popular sweet taste with acidic nature, high nutritive value and medical importance, it hasn't been so far utilized (Bakry, 2003).

Drying of agricultural products, a common method of natural preservation by reducing the moisture content to a level at which microbial spoilage is minimized and the product is relatively chemically stable has always been a significant contribution to the income of the agricultural societies (Krokida and Marinos-Koouris, 2003 \& Abd El-Ghaffar, 2009). Mechanical air dehydration has gained importance because it has many advantages over sun-drying. These include: (a) the process is under better sanitary conditions, (b) drying parameters can be accurately set, controlled and changed over the entire processing time, thus a more consistently uniform product can be achieved with less quality degradation (Barbosa-Canovas and VegaMercado, 1996 \& Tosun and Delen, 1998). Using convective hot-air drying method in which, food materials are exposed to elevated drying temperatures, leads to an increase in shrinkage and toughness, reduction of both the bulk density and rehydration capacity of the dried product and also causes serious damage in flavour, colour and nutrient content. The major draw-back of convective hot-air drying method, from an energy point of view, is the longer drying period, higher drying temperature and therefore high energy consumption, which may be as high as 6000 $\mathrm{kJ} / \mathrm{kg}$ of water evaporated (Mujumdar and Menon, 1995, Maskan, 2000 \& Alibas, 2007). The desire to reduce the above problems, as well as to achieve fast and effective thermal process lead to the use of microwave and dielectric heating method for food drying. Microwaves are not forms of heat, but rather forms of energy that are manifested as heat through their interaction with materials. It is as if they cause the materials to heat themselves. (Bondaruk, et al , 2007). 
Microwave energy is rapidly absorbed by water molecules which, consequently, results in rapid evaporation of water and thus higher drying rates. Therefore microwave drying offers significant energy savings, with a potential reduction in drying times of up to $50 \%$ in addition to the inhibition of surface temperature of treated material (Schiffmann, 1995). Drying conditions or drying equipments can be modified to increase overall efficiencies. Hybrid drying techniques can be used, such as combining vacuum or convective drying with electro-technologies such as microwave, radio frequency and infrared heating (Raghavan et al., 2005). This research was undertaken to study the physical and chemical properties of fresh husk tomato as well as the influence of the drying pretreatments and the drying methods (oven drying and combined oven drying/microwave drying) on the drying behaviour of the fruit. The effect of drying pretreatments and storage on the chemical composition and the organoleptic characteristics of dried husk tomato as well as the application of the dried fruit on some food products were also studied.

\section{MATERIALS AND METHODS}

\section{Materials:}

Husk tomato (Physalis pruinosa L.) was purchased from Alexandria Governorate local market, Egypt in February 2011. Olive oil, wheat flour (72\% extraction), sugar, butter, liquid milk, eggs, baking powder, salt, vanilla and crude chocolate were purchased from Alexandria market, Egypt. Sodium metabisulphite was obtained from El-Nasr company and sodium carbonate was obtained from El-Gomhoria company, Egypt.

\section{Methods}

\section{Technological methods}

\section{Husk tomato drying}

Husk tomato sample was manually peeled and washed with tap water. Chemical pretreatments consisted of immersing the sample, during a pre- determined time interval, in aqueous suspensions of commercial olive oil and $\mathrm{Na}_{2} \mathrm{CO}_{3}$ (solution to fruit was $2: 1 \mathrm{v} / \mathrm{w})$. Solutions of the desired concentration of $\mathrm{Na}_{2} \mathrm{CO}_{3}$ were prepared in tap water and heated at $50^{\circ} \mathrm{C}$, on a hot plate with stirring. Olive oil was then slowly poured into this solution, which was kept under continuous agitation during dipping of berries. The levels of $\mathrm{Na}_{2} \mathrm{CO}_{3}$ and olive oil concentrations, as well as, time of dipping are shown in Table (1). A full factorial experiment in three factors (A, B and C) with various levels was carried out according to Dean and Voss (2005). Sulphiting of pretreated husk tomato berries was carried out by dipping in $0.1 \%$ sodium metabisulphite solution for $2 \mathrm{~min}$ (Control sample was sulphited only).

\section{Hot air drying of husk tomato}

The prepared husk tomatoes were loaded on wire trays at rate of $1.3 \mathrm{~g} / \mathrm{cm}^{2}$ then dried at $40^{\circ} \mathrm{C}$ for $4 \mathrm{hrs}$ and continued at $65^{\circ} \mathrm{C}$ until the moisture content of the samples reached the equilibrium moisture content $10: 12 \%$. The dried samples were packed in polyethylene bags and stored at room temperature until used.

\section{Hot air/microwave drying of husk tomato}

The most preferable treatment as stated by the panelists (treatment cod. A2B1C2) was dried by hot air/microwave in order to compare it with that dried by hot air (Table 2). Husk tomatoes were loaded in wire trays and dried at $40^{\circ} \mathrm{C}$ for $4 \mathrm{hrs}$ and continued at $65^{\circ} \mathrm{C}$ for $6 \mathrm{hrs}$. The dried berries (about $1 \mathrm{Kg}$ ) were placed in glass dish (diameter $28 \mathrm{~cm}$ and $1.7 \mathrm{~cm}$ depth)at the center of the microwave cavity. The cycle for operating the microwave oven was 1 min ON then 5 minutes OFF. This cycle was repeated until the moisture content of the samples reached the equilibrium moisture content $10: 12 \%$. The dried samples were packed in polyethylene bags and stored at room temperature until used.

Table 1. Different pretreatments of husk tomato

\begin{tabular}{|c|c|c|c|}
\hline Code & $\begin{array}{l}\text { Sod. carbonateConc. (\%) } \\
\text { (A) }\end{array}$ & $\begin{array}{l}\text { Olive oil conc. }(\%) \\
\text { (B) }\end{array}$ & $\begin{array}{l}\text { Dipping time (min) } \\
\text { (C) }\end{array}$ \\
\hline $\mathrm{A} 1 \mathrm{~B} 1 \mathrm{C} 1$ & 0 & 0 & 2 \\
\hline $\mathrm{A} 1 \mathrm{~B} 1 \mathrm{C} 2$ & 0 & 0 & 4 \\
\hline $\mathrm{A} 1 \mathrm{~B} 2 \mathrm{C} 1$ & 0 & 0.5 & 2 \\
\hline $\mathrm{A} 1 \mathrm{~B} 2 \mathrm{C} 2$ & 0 & 0.5 & 4 \\
\hline $\mathrm{A} 2 \mathrm{~B} 1 \mathrm{C} 1$ & 3 & 0 & 2 \\
\hline $\mathrm{A} 2 \mathrm{~B} 1 \mathrm{C} 2$ & 3 & 0 & 4 \\
\hline $\mathrm{A} 2 \mathrm{~B} 2 \mathrm{C} 1$ & 3 & 0.5 & 2 \\
\hline $\mathrm{A} 2 \mathrm{~B} 2 \mathrm{C} 2$ & 3 & 0.5 & 4 \\
\hline A3B1C1 & 6 & 0 & 2 \\
\hline $\mathrm{A} 3 \mathrm{~B} 1 \mathrm{C} 2$ & 6 & 0 & 4 \\
\hline A3B2C1 & 6 & 0.5 & 2 \\
\hline A3B2C2 & 6 & 0.5 & 4 \\
\hline
\end{tabular}


Table 2. husk tomato pretreatments for hot air/microwave drying

\begin{tabular}{cccc}
\hline Code & $\begin{array}{c}\text { Sod. carbonateConc. (\%) } \\
\text { (A) }\end{array}$ & $\begin{array}{c}\text { Olive oil conc. (\%) } \\
\text { (B) }\end{array}$ & $\begin{array}{c}\text { Dipping time (min) } \\
\text { (C) }\end{array}$ \\
\hline HA/MW (A2B1C2) & 3 & 0 & 4 \\
\hline Preparation of cake with dried husk tomato & Faculty of Agriculture, Alexandria University, Egypt, \\
Cakes were prepared according to the basic formula & using a numerical (hedonic) rating of 1-10 (1= dislike \\
described by El-Abasy (2011) and Gomez et al (2011) & very much, 10= like very much) as described by Abd \\
with some modifications. The formula included 100 $\mathrm{g}$ & El-Lahot (2010).
\end{tabular}
all purpose wheat flour ( $72 \%$ extraction), $120 \mathrm{~g}$ white sugar, $50 \mathrm{~g}$ whole egg, $60 \mathrm{~g}$ liquid milk, $30 \mathrm{~g}$ butter, $3 \mathrm{~g}$ baking powder. Mechanical mixer (momnanlex, type MAR.765) was used to prepare the cake batter. Batter was first creamed and sugar was added gradually while creaming was continued. Eggs were beaten into the creamed mixture. Flour was sifted with baking powder and added alternately with milk. Dried husk tomato was added to formula at concentration of $15 \%$ of wheat flour weight. Cake batter was poured into an aluminum foil pan and baked at $200^{\circ} \mathrm{C}$ for $25 \mathrm{~min}$. After baking, cakes were removed from the pan, left to cool for $1 \mathrm{~h}$ at room temperature, and packed into hermetically sealed plastic bags to prevent drying and subjected to organoleptic test.

\section{Preparation of coated chocolate husk tomato}

Crude chocolate was melted by heating in water bath and the dried husk tomato was dipped in the melted chocolate, then removed and cooled to room temperature and packed in polyethylene bags and subjected to organoleptic test.

\section{Drying curve}

According to Hamed (2008), the pretreated samples were placed in a dryer (oven dryer or microwave dryer). Weight of the pretreated samples was measured in fixed time intervals and recorded as a function of drying time. The drying data obtained were then expressed as moisture ratio (MR) according to the following equation:

$\mathrm{MR}=\frac{\mathrm{M}}{\mathrm{Mi}}$

Where:

$\mathrm{MR}=$ Moisture ratio

$\mathrm{M}=\%$ Moisture content (dry basis) at the fixed time intervals.

$\mathrm{Mi}=\%$ Initial moisture content (dry basis).

The calculated MR,s were plotted against the drying times to obtain the drying curve.

\section{Sensory evaluation}

Appearance, colour, odour, taste, texture and overall acceptability of tested samples were assessed by ten panelists of Food Science and Technology Department,

\section{Storage of samples}

The dried samples that had high scores by panelists were packaged in bags of polyethylene and stored for a period of six months at room temperature. Samples were taken for analysis every three months of storage. The experiments were performed in nested design according to Dean and Voss (2005).

\section{Method of analysis:}

\section{Physical properties:}

Fruit weight of fig varieties were measured by sensitive balance (Jadever, Surg-30*0.01g). Fruit dimensions (length and width), ostiole width and thickness of skin were measured by micrometer. The fruit index was calculated by dividing the width by the length (width/length) according to Polat and Caliskan (2008). Total soluble solids (TSS) \% of fig varieties were determined by using a hand refrectometer (ATAGO, Japan. $0 \approx 50 \%$ ) using the method mentioned in A.O.A.C. (2000). The $\mathrm{pH}$ values of fresh and dried samples of fig were measured according to El-Abasy (2011). Approximately $5 \mathrm{~g}$ sample was homogenized with $30 \mathrm{ml}$ distilled water in homogenizer for $10 \mathrm{~min}$ and the filtered solution was used for $\mathrm{pH}$ estimation by digital $\mathrm{pH}$ meter (Martini, Bench meter Mi 150). Colour of fresh and dried samples of fig was determined using a Hunter Lab Eazy MatchQC (L*, a*, b*) according to Caliskan and Polat (2011). The $\mathrm{L}^{*}$ value represents lightness (L* 0 for black, $L^{*} 100$ for white), whereas the $\mathrm{a}^{*}$ scale represents the red/green dimension, with positive values for red and negative ones for green. The $b^{*}$ scale represents the yellow/blue dimension, with positive values for yellow and negative ones for blue. $\mathrm{L}^{*}, \mathrm{a}^{*}$, and $\mathrm{b}^{*}$ values were measured on three different spots in each samples. The results were recorded as the mean of these measurements. The chroma $\left(\mathrm{C}^{*}\right)$ value, calculated as $=\left(a^{* 2}+b^{* 2}\right)^{1 / 2}$ indicates colour intensity. Hue angle a parameter that has been shown to be effective in predicting visual colour appearance, was calculated using the formula hue ${ }^{\circ}=\tan ^{-1}\left(\mathrm{~b}^{*} / \mathrm{a}^{*}\right)$, where $0^{\circ}$ or $360^{\circ}=$ red-purple, $90^{\circ}=$ yellow, $180^{\circ}=$ green, and $270^{\circ}=$ blue.

\section{Chemical analysis:}

Fresh and dehydrated samples of fig varieties were minced in Braun mixer and subjected to the following 
analysis. Moisture, total, reducing and non reducing sugars, crude protein, crude ether extract, total ash, crude fibre, titratable acidity and ascorbic acid were determined as described by AOAC procedures (2003) unless otherwise stated. Minerals including $\mathrm{Ca}, \mathrm{Mg}$ were measured described in the AOAC (2000) using Perkin Elmer Atomic Absorption spectrophotometer (Model 2380). On the other hand, $\mathrm{K}$ and $\mathrm{Na}$ were determined using flame photometer (Model PEP7, U.K.).

Pectin substances were measured according to Bekheit (2002). Fifty g samples were added to $400 \mathrm{ml}$ distilled water and boiled for an hr at a constant volume. The extract was diluted with water to $500 \mathrm{ml}$ in a volumetric flask and then filtered through Whatman paper No. 41. One hundred $\mathrm{ml}$ of the filtrate was diluted with an equal volume of distilled water, ten $\mathrm{ml}$ of $1 \mathrm{~N}$ sodium hydroxide solution were added to the mixture and the solution was allowed to stand overnight, then, fifty $\mathrm{ml}$ of $1 \mathrm{M}$ acetic acid solution were added. After five min later, $25 \mathrm{ml}$ of $1 \mathrm{M}$ calcium chloride solution were added. The mixture was allowed to stand for an hr before boiling for one min, followed by hot filtration through a Whatman filter paper No. 41 previously weighed. The filter paper was washed with hot water until all traces of chloride were eliminated. The filter paper with the precipitate was dried at $105^{\circ} \mathrm{C}$ for $3 \mathrm{hrs}$ and then cooled before weighing. Redrying was carried out for half an hr to ensure that no further weight loss had occurred. The weight of the precipitate represents the weight of the soluble pectin.

The method recommended for determination of total phenols using Folin-Ciocalteau reagent was adapted from Mc Donald et al (2001) \& Konyaloglu et al (2005). Samples (10 g) were extracted by methanol: water $(50: 50, \mathrm{v} / \mathrm{v})$ and left for $30 \mathrm{~min}$ with stirring. Test solutions of $0.5 \mathrm{ml}$ were added to $4.0 \mathrm{ml}$ of $1 \mathrm{M} \mathrm{Na}_{2} \mathrm{CO}_{3}$. Five milliliters of Folin-Ciocalteau reagent $(1: 10, \mathrm{v} / \mathrm{v})$ were added and the solutions were allowed to stand at $45^{\circ} \mathrm{C}$ in water bath for $15 \mathrm{~min}$. Absorbance were measured at $750 \mathrm{~nm}$. The blank consisted of all reagents and solvents without test compounds or standard. The standard was gallic acid prepared in concentrations of 50 to $200 \mathrm{mg} / \mathrm{L}$. This is commonly used as a reference compound. The Phenolic concentrations were determined by comparison with the standard calibration curve. Total phenol values were expressed as gallic acid equivalents ( $\mathrm{mg} \mathrm{g}^{-1}$ dry mass).

According to Caliskan and Polate (2011), the total anthocyanin (TA) content was quantified according to the $\mathrm{pH}$ differential method. Absorbance (A) was $\mathrm{DMPD}_{\text {(uncoloured) }}+$ oxidant $\left(\mathrm{Fe}^{3-}\right)+\mathrm{H}^{+}$ $\mathrm{DMPD}^{+}{ }_{\text {(purple coloured radical cation) }}+\mathrm{AOH}_{\text {(antioxidant material) }}$ measured at 520 and 700nm in buffers at $\mathrm{pH} 1.0$ and $\mathrm{pH}$ 4.5 where $\left.\mathrm{A}=\mathrm{A}_{520}-\mathrm{A}_{700}\right)$ ph 1.0- $\left(\mathrm{A}_{520}-\mathrm{A}_{700}\right) \mathrm{pH}$ 4.5. The buffers were potassium chloride buffer, $0.025 \mathrm{M}$, pH 1.0 and sodium acetate buffer, $0.4 \mathrm{M}, \mathrm{pH} 4.5$ according to Wrlstad et al. (2005). Results were expressed as $\mu \mathrm{g}$ cyaniding-3- rutinoside (molar extinction coefficient of 28,800 and molecular weight of 595.2) (Soloman et al., 2006) equivalents per $g$ fresh weight of fruit.

Antioxidant activity was measured by the N,Ndimethyl- $p$-phenylenediamine dihydrochloride (DMPD) according to Fogliano et al (1999). Two hundred and nine $\mathrm{ml}$ of DMPD were dissolved in $10 \mathrm{ml}$ of deionized water. One $\mathrm{ml}$ of this solution was added to $100 \mathrm{ml}$ of $0.1 \mathrm{M}$ acetate buffer $(\mathrm{pH}=5.25)$ then $0.2 \mathrm{ml}$ of $0.05 \mathrm{M}$ ferric chloride solution was added to obtain coloured radical cation $\left(\mathrm{DMPD}^{+}\right)$as follows:

One $\mathrm{ml}$ of this solution was directly placed in a $1 \mathrm{ml}$ plastic cuvette and its absorbance was measured at 505 nm using Spekol Spectrocolorimeter (Spekol 11, Carlzeiss Jena). Standard solution of the antioxidant compound was prepared as follows: A weight of $0.1 \mathrm{~g}$ of ascorbic acid was dissolved in $100 \mathrm{ml}$ of deionized water to obtain $1 \mathrm{mg} / \mathrm{ml}$ of ascorbic acid. $10 \mathrm{~g}$ samples were extracted by $100 \mathrm{ml}$ methanol and then centrifuged. A volume of $50 \mu \mathrm{l}$ of standard antioxidant or sample extraction was added in the spectrometric cuvette contained $1 \mathrm{ml}$ of $\mathrm{DMPD}^{+}$solution, and after 10 min at $25^{\circ} \mathrm{C}$ under continuous stirring, the absorbance was measured at $505 \mathrm{~nm}$. Buffered solution was placed in the reference cuvette.

A dose-response curve was derived for ascorbic acid, by plotting the absorbance at $505 \mathrm{~nm}$ as percentage of the absorbance of the uninhibited radical cation solution according to the following equation:

Inhibition of $\mathrm{A}_{505}(\%)=\left(1-\left(\frac{\mathrm{AF}}{\mathrm{AO}}\right)\right) \times 100$
Where:

$\mathrm{A} 0=$ absorbance of uninhibited radical cation.

$\mathrm{AF}=$ absorbance measured at $10 \mathrm{~min}$ after the addition of antioxidant samples.

Total and free sulphur dioxide as ( $\mathrm{ppm}$ ) were determined using the iodine titration method as described by Ranganna (1995).

The method recommended by Gouda (1974) was used to determine the rehydration ratio. Ten grams of dried samples were placed in $600 \mathrm{ml}$ beaker and a definite volume $(100 \mathrm{ml})$ of tap water was added, covered by watch glass. Boiling was brought within 3 $\mathrm{min}$ and continued for $30 \mathrm{~min}$.

$\mathrm{DMPD}^{+}{ }_{\text {(purple coloured radical cation) }}$

$\mathrm{DMPD}_{\text {(uncoloured) }}+\mathrm{AO}_{\text {(antioxidant compounds). }}$ 
The content was then transferred to a Buchnner funnel and left for $1 \mathrm{~min}$ before weighing. Rehydration ratio was expressed as the ratio between the drained weight of the rehydration sample and the weight of the dehydration sample.

\section{Microbiological analysis}

Microbial analysis was carried out aseptically by mixing $10.0 \mathrm{~g}$ of different samples that had the highest scores by panelists along with the control and the stored samples with $90.0 \mathrm{ml}$ sterile $0.1 \%$ peptone water using a blender (stainless steel). Serial dilutions were made. The total aerobic mesophillic bacterial count and yeast/molds count were carried out using nutrient agar at $30^{\circ} \mathrm{C}$ for $48 \mathrm{~h}$ and potato dextrose agar at $25^{\circ} \mathrm{C}$ for $3-$ 5 days, respectively, according to Oztekin et al (2006).

\section{Statistical analysis}

The analysis of data was performed as an analysis of variance (ANOVA) and significant differences were assessed with an LSD test $(\mathrm{p}<0.05)$ according to Dean and Voss (2005) by using statistical software package "STATISTICA 7.0"

\section{RESULTS AND DISCUSSION}

\section{Physical properties of fresh husk tomato}

Table (3) shows the physical properties of fresh husk tomato. From this Table, it can be concluded that the average fruit weight, length, width, fruit index and the number of fruit per kilogram were $3.92 \mathrm{gm}, 1.86$ $\mathrm{cm}, 1.87 \mathrm{~cm}, 1.01$ (globose shape) and 319.7. The obtained results are not in accordance with those reported by Abou-Gharbia and Abou-Tour (2001) and Bakry (2003) which may be due to species, environmental and agricultural conditions as well as

Table 3. Physical properties total soluble solids, $\mathrm{pH}$ and titratable acidity of fresh husk tomato

\begin{tabular}{|c|c|}
\hline Properties & Value $^{*}$ \\
\hline Weight (gm) & $3.92 \pm 0.83$ \\
\hline Number of fruit per kilogram & $319.7 \pm 26.1$ \\
\hline Length $(\mathrm{cm})$ & $1.86 \pm 0.14$ \\
\hline Width $(\mathrm{cm})$ & $1.87 \pm 0.20$ \\
\hline Fruit index (width/length) & $1.01 \pm 0.07$ \\
\hline Husk (\%) & $7.78 \pm 0.03$ \\
\hline Yield after dehusking (\%) & $92.22 \pm 0.03$ \\
\hline T.S.S. $(\%)$ & $12.1 \pm 1.9$ \\
\hline $\mathrm{pH}$ & $3.68 \pm 0.1$ \\
\hline Titratable acidity $(\%)^{* *}$ & $1.72 \pm 0.06$ \\
\hline Titratable acidity $(\%)^{* * *}$ & $9.29 \pm 0.34$ \\
\hline T.S.S./Acidity & $7.39 \pm 0.57$ \\
\hline
\end{tabular}

time of harvesting. On the other hand, the percentage of husk and the yield after dehusking were 7.78 and $92.22 \%$, respectively. The results obtained here are in accordance with those reported by Abou-Gharbia and Abou-Tour (2001) and Bakry (2003).

Table (3) shows also the T.S.S., pH, titratable acidity and T.S.S./acidity and the values were $12.1 \%$, $3.68,1.72 \%$ and 7.39 , respectively. The percentage of T.S.S. was nearly close to that reported by Cantwell et al (1992) and was very smaller than that presented by Bakry (2003) and Abou-Gharbia \& Abou-Tour (2001). The titratable acidity of fresh husk tomato was higher than that reported by Abou-Gharbia and AbouTour (2001) and smaller than that mentioned by Bakry (2003), while, the $\mathrm{pH}$ value was smaller than that reported by Abou-Gharbia and Abou-Tour (2001) and higher than that presented by Bakry ( 2003).

\section{Chemical composition of fresh husk tomato}

The percentages of moisture, sugars (total, reducing and non-reducing), crude protein, total pectin, crude fibre, total ash, crude ether extract, ascorbic acid and phenolic content of fresh husk tomato are shown in Table (4). Moisture content was $81.49 \%$ and agreed well with that reported by Abou-Gharbia and AbouTour (2001). Moreover, the sugars (total, reducing and non-reducing) were $54.22,25.26$ and $28.96 \%$ on dry weight basis, respectively. Although, the total sugars were similar to that reported by Bakry (2003), reducing sugars were higher than that reported by Abou-Gharbia and Abou-Tour (2001) \& Bakry (2003). The obtained results indicated that non-reducing sugars accounted about $52.01 \%$ of the total sugars. 
Table 4. Chemical composition of fresh husk tomato

\begin{tabular}{|c|c|}
\hline Component & Value $^{*}$ \\
\hline Moisture (\%) & $81.49 \pm 0.20$ \\
\hline Total sugars $(\%)$ & $54.22 \pm 1.87$ \\
\hline Reducing sugars (\%) & $25.26 \pm 2.16$ \\
\hline Non-reducing sugars (\%) & $28.96 \pm 1.56$ \\
\hline Crude protein $(\%)$ & $12.75 \pm 0.13$ \\
\hline Total pectin $(\%)$ & $1.29 \pm 0.08$ \\
\hline Crude fibre $(\%)$ & $19.38 \pm 1.42$ \\
\hline Total ash (\%) & $5.98 \pm 0.20$ \\
\hline Crude ether extract (\%) & $4.96 \pm 0.17$ \\
\hline Calcium (ppm) & 113.58 \\
\hline Magnesium (ppm) & 317.04 \\
\hline Sodium (ppm) & 1106.62 \\
\hline Potassium (ppm) & 6034.01 \\
\hline Ascorbic Acid (mg/100g) & $178.88 \pm 1.62$ \\
\hline Phenolic content $(\mathrm{mg} / \mathrm{gm})^{* *}$ & $7.48 \pm 0.25$ \\
\hline $\mathrm{TAC}^{* * *}$ & $21.43 \pm 1.24$ \\
\hline
\end{tabular}

* Mean \pm S.D on dry weight basis

** mg gallic acid.

*** TAC is Total Antioxidant Capacity as ascorbic acid equivalent.

Crude protein content of fresh husk tomato was $12.75 \%$ on dry weight basis and this value agreed well with that obtained by Abou-Gharbia and Abou-Tour (2001). They found that the crude protein content was $12.88 \%$ on dry weight basis. Total pectin content was $1.29 \%$ and disagreed with that reported by Cantwell et al (1992) and Abou-Gharbia and Abou-Tour (2001). On the other hand, crude fibre of husk tomato was $19.38 \%$ on dry weight basis. This value was quite close to that reported by Bakry (2003). Total ash content of husk tomato was $5.98 \%$ on dry weight basis. This value was nearly quite close to that presented by Abou-Gharbia and Abou-Tour (2001). Also, minerals include $\mathrm{Ca}, \mathrm{Mg}$, $\mathrm{Na}$, and $\mathrm{K}$ was $113.58,317.04,1106.62$ and 6034.01 ppm (on dry weight basis), respectively. These values were slightly higher than that reported by Bakry (2003).

Crude ether extract of fresh husk tomato was $4.96 \%$ on dry weight basis. This value disagreed with the value reported by Abou-Gharbia and Abou-Tour (2001), who reported that, crude ether extract was $5.70 \%$ on dry weight basis. On the other hand, the obtained value was higher than that reported by Bakry (2003), who found that the crude ether extract content of husk tomato was $0.44 \%$ on dry weight basis. Ascorbic acid content was $178.88 \mathrm{mg} / 100 \mathrm{gm}$ on dry weight basis. These results are not comparable with those reported by AbouGharbia and Abou-Tour (2001). They found that ascorbic acid content of husk tomato was 39.5 $\mathrm{mg} / 100 \mathrm{gm}$. Further, phenolic content as gallic acid and the total antioxidant capacity as ascorbic acid equivalent of husk tomato were $7.48 \mathrm{mg} / \mathrm{g}$ and $21.43 \mathrm{mg} / \mathrm{g}$ on dry weight basis.

Effect of pretreatments and drying methods on the drying behaviour of husk tomato

The drying curves of all conducted drying tests are illustrated in Figs (1-4). The moisture ratio (MR) was plotted versus drying time for the different pretreatments and the different drying methods.

The presented data in Table (5) indicated that the drying time for husk tomato by hot air varied from 932.3 to $1225 \mathrm{~min}(15.5-20.34 \mathrm{hr})$ depending on the pretreatments applied before drying.

The effect of drying by hot air/microwave is shown in Table (5). Hot air/microwave drying had a great effect on reduction of drying time. The drying time decreased from 994.3 to $645.3 \mathrm{~min}(16.6-10.75 \mathrm{hr})$ for sample A2B1C2 that has been dried by hot air or dried by hot air/microwave, respectively. Hot air/microwave drying decreased the time required to achieve the final moisture content by about $35 \%$. The results also indicated that drying time decreased with increasing $\mathrm{Na}_{2} \mathrm{CO}_{3}$ concentration with no significant differences between concentration $3 \%$ and $6 \%$ of $\mathrm{Na}_{2} \mathrm{CO}_{3}$. The same trend was observed with olive oil concentrations. The drying time decreased from 1106.2 to $1001.5 \mathrm{~min}$ (18.43 to $16.7 \mathrm{hr}$ ) when olive oil concentration increased from 0 to $0.5 \%$. Also, immersion time had great effect on drying time, when immersion time increased from 2 to $4 \mathrm{~min}$ the drying time decreased from 1081.5 to $1026.3 \mathrm{~min}$ (18 to $17.1 \mathrm{hr}$ ). From the statistical point of view, it can be concluded that the lowest drying time was observed for A2B2C2, A3B2C1 and $\mathrm{A} 3 \mathrm{~B} 2 \mathrm{C} 2$, respectively. 


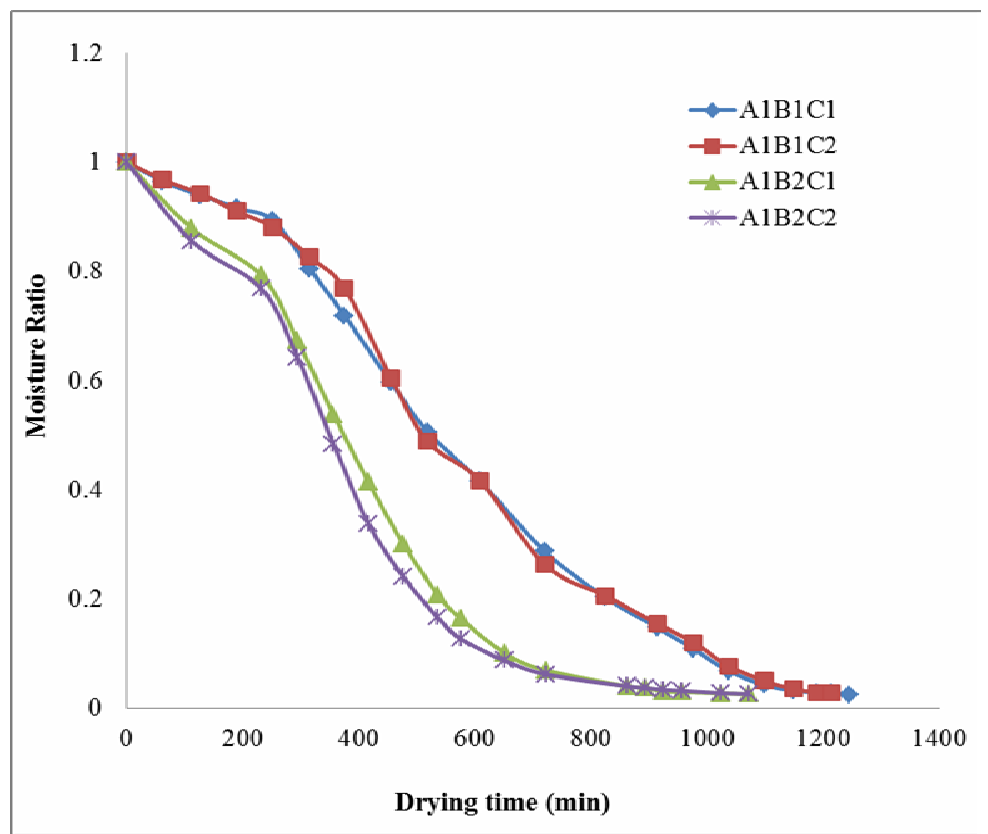

Fig 1. Hot air drying curves of husk tomato at different pretreatments A1B1C1 $=0 \% \mathrm{Na}_{2} \mathrm{CO}_{3}, 0 \%$ olive oil, 2 min dipping time. A1B1C2 $=0 \% \mathrm{Na}_{2} \mathrm{CO}_{3}, 0 \%$ olive oil, 4 min dipping time. A1B2C $1=0 \% \mathrm{Na}_{2} \mathrm{CO}_{3}, 0.5 \%$ olive oil, 2 min dipping time. A1B2C $=0 \% \mathrm{Na}_{2} \mathrm{CO}_{3}, 0.5 \%$ olive oil, 4 min dipping time.

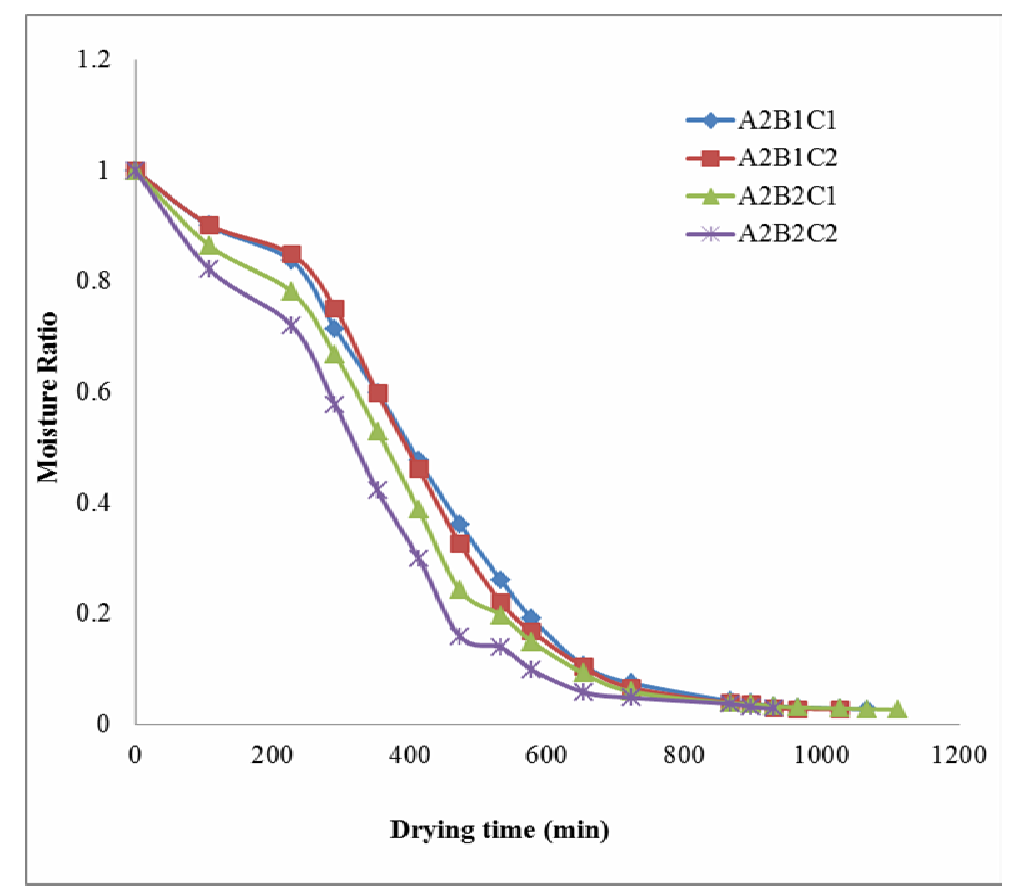

Fig 2. Hot air drying curves of husk tomato at different pretreatments A2B1C1 $=3 \% \mathrm{Na}_{2} \mathrm{CO}_{3}, 0 \%$ olive oil, 2 min dipping time. A2B1C2 $=3 \% \mathrm{Na}_{2} \mathrm{CO}_{3}, 0 \%$ olive oil, 4 min dipping time. A2B2C1 $=3 \% \mathrm{Na}_{2} \mathrm{CO}_{3}, 0.5 \%$ olive oil, 2 min dipping time. A2B $2 \mathrm{C} 2=3 \% \mathrm{Na}_{2} \mathrm{CO}_{3}, 0.5 \%$ olive oil, 4 min dipping time. 


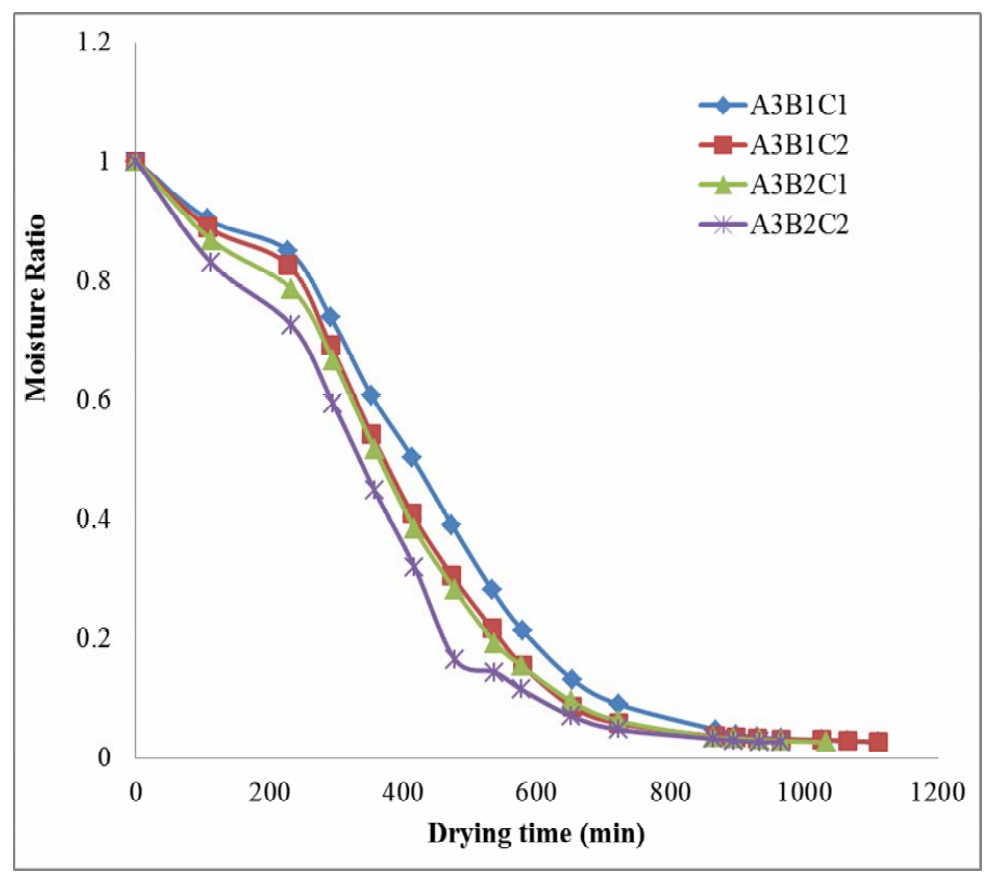

Fig 3. Hot air drying curves of husk tomato at different pretreatments A3B1C1 $=6 \% \mathrm{Na}_{2} \mathrm{CO}_{3}, 0 \%$ olive oil, 2 min dipping time. A3B1C2 $=6 \% \mathrm{Na}_{2} \mathrm{CO}_{3}, 0 \%$ olive oil, 4 min dipping time. A3B2C1 $=6 \% \mathrm{Na}_{2} \mathrm{CO}_{3}, 0.5 \%$ olive oil, 2 min dipping time. A3B2C $2=6 \% \mathrm{Na}_{2} \mathrm{CO}_{3}, 0.5 \%$ olive oil, 4 min dipping time.

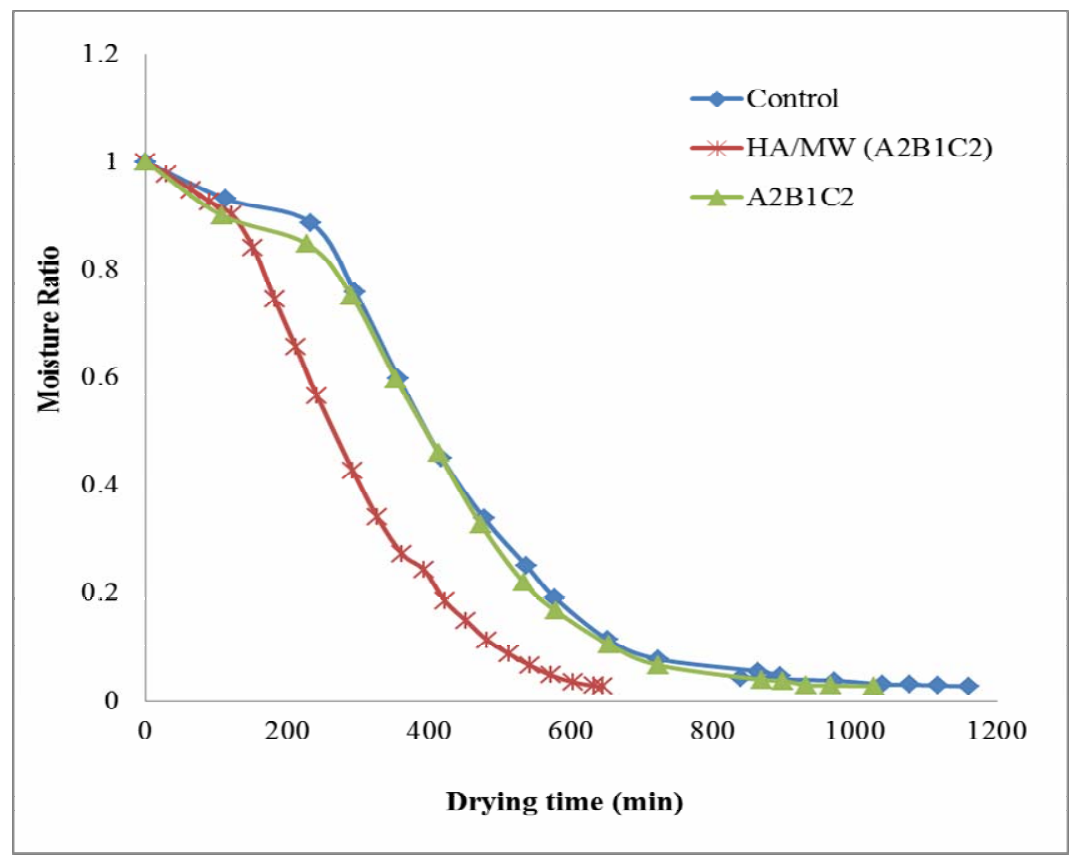

Fig 4.Drying curves of husk tomato at different pretreatments and different drying methods (hot air drying and hot air/microwave drying)

Control $=0 \% \mathrm{Na}_{2} \mathrm{CO}_{3}, 0 \%$ olive oil, 0 min dipping time.

A2B1C2 $=3 \% \mathrm{Na}_{2} \mathrm{CO}_{3}, 0 \%$ olive oil, 4 min dipping time and dried by hot air

$\mathrm{HA} / \mathrm{MW}(\mathrm{A} 2 \mathrm{~B} 1 \mathrm{C} 2)=3 \% \mathrm{Na}_{2} \mathrm{CO}_{3}, 0 \%$ olive oil, 4 min dipping time and dried by hot air/microwave. 
Table 5. Drying time at different pretreatments and different drying methods of husk tomato

\begin{tabular}{|c|c|}
\hline Code of treatment & Drying time $^{*}$ (min) \\
\hline \multicolumn{2}{|l|}{ Hot air Drying } \\
\hline A1B1C1 & $1225.0 \pm 17.3^{\mathrm{a}}$ \\
\hline A1B1C2 & $1185.0 \pm 27.8^{\mathrm{ab}}$ \\
\hline A1B2C1 & $1051.7 \pm 19.6^{\mathrm{cd}}$ \\
\hline $\mathrm{A} 1 \mathrm{~B} 2 \mathrm{C} 2$ & $1001.5 \pm 69.5^{\mathrm{def}}$ \\
\hline $\mathrm{A} 2 \mathrm{~B} 1 \mathrm{C} 1$ & $1044.3 \pm 19.9^{\text {cd }}$ \\
\hline $\mathrm{A} 2 \mathrm{~B} 1 \mathrm{C} 2$ & $994.3 \pm 30.7^{\text {efg }}$ \\
\hline $\mathrm{A} 2 \mathrm{~B} 2 \mathrm{C} 1$ & $1087.5 \pm 22.6^{\mathrm{c}}$ \\
\hline $\mathrm{A} 2 \mathrm{~B} 2 \mathrm{C} 2$ & $932.3 \pm 32.6^{\mathrm{h}}$ \\
\hline A3B1C1 & $1085.7 \pm 23.0^{c}$ \\
\hline A3B1C2 & $1087.5 \pm 22.6^{\mathrm{c}}$ \\
\hline $\mathrm{A} 3 \mathrm{~B} 2 \mathrm{C} 1$ & $984.0 \pm 50.0^{\mathrm{fg}}$ \\
\hline $\mathrm{A} 3 \mathrm{~B} 2 \mathrm{C} 2$ & $950.0 \pm 16.5^{\mathrm{gh}}$ \\
\hline control & $1161.7 \pm 12.6^{\mathrm{b}}$ \\
\hline \multicolumn{2}{|l|}{ Hot air/microwave drying } \\
\hline HA/MW (A2B1C2) & $645.3 \pm 4.2^{\mathrm{i}}$ \\
\hline
\end{tabular}

Means in a column not sharing the same superscript are significantly different at $\leq 0.5$

Effect of pretreatments on the organoleptic characteristics of dried husk tomato.

All the air dried husk tomato samples were judged by panelists immediately after drying process for appearance, colour, odour, taste, texture and overall acceptability and the results are shown in Table (6).

The appearance of sample $\mathrm{A} 2 \mathrm{~B} 1 \mathrm{C} 2$ had the highest score followed by $\mathrm{A} 3 \mathrm{~B} 2 \mathrm{C} 1$ and $\mathrm{A} 2 \mathrm{~B} 1 \mathrm{C} 1$, respectively. On the other hand, samples $\mathrm{A} 1 \mathrm{~B} 1 \mathrm{C} 1, \mathrm{~A} 3 \mathrm{~B} 1 \mathrm{C} 2$ and $\mathrm{A} 3 \mathrm{~B} 2 \mathrm{C} 2 \mathrm{had}$ the lowest score for appearance.
Further, samples $\mathrm{A} 2 \mathrm{~B} 1 \mathrm{C} 1$ and $\mathrm{A} 2 \mathrm{~B} 1 \mathrm{C} 2$ had the highest colour score followed by $\mathrm{A} 3 \mathrm{~B} 2 \mathrm{C} 1$, whereas, $\mathrm{A} 3 \mathrm{~B} 1 \mathrm{C} 2$ and $\mathrm{A} 3 \mathrm{~B} 2 \mathrm{C} 2$ had the lowest colour score. No significant differences were noticed between all samples with respect to their odour and texture.

The same trend was observed for taste and overall acceptability. Sample A2B1C2 is moderately high followed by $\mathrm{A} 3 \mathrm{~B} 2 \mathrm{C} 1$, while sample $\mathrm{A} 1 \mathrm{~B} 1 \mathrm{C} 2$ had the lowest taste score and sample $\mathrm{A} 3 \mathrm{~B} 1 \mathrm{C} 2$ had the lowest overall acceptability score.

Table 6. Organoleptic characteristics of air dried husk tomato*

\begin{tabular}{ccccccc}
\hline treatment & Appearance & Colour & Odour & Taste & Texture & $\begin{array}{c}\text { Overall } \\
\text { acceptability }\end{array}$ \\
\hline A1B1C1 & $6.1 \pm 2.2^{\mathrm{c}}$ & $6.3 \pm 2.1^{\mathrm{c}}$ & $6.8 \pm 2.0^{\mathrm{a}}$ & $5.9 \pm 2.2^{\mathrm{cd}}$ & $6.9 \pm 1.9^{\mathrm{a}}$ & $6.5 \pm 0.5^{\mathrm{cdef}}$ \\
\hline $\mathrm{A} 1 \mathrm{~B} 1 \mathrm{C} 2$ & $6.5 \pm 2.1^{\mathrm{abc}}$ & $6.6 \pm 2.1^{\mathrm{bc}}$ & $6.7 \pm 1.6^{\mathrm{a}}$ & $5.5 \pm 2.5^{\mathrm{d}}$ & $6.8 \pm 2.0^{\mathrm{a}}$ & $6.4 \pm 0.5^{\mathrm{def}}$ \\
\hline $\mathrm{A} 1 \mathrm{~B} 2 \mathrm{C} 1$ & $7.4 \pm 1.2^{\mathrm{ab}}$ & $6.6 \pm 1.2^{\mathrm{bc}}$ & $6.9 \pm 1.6^{\mathrm{a}}$ & $6.1 \pm 1.8^{\mathrm{bcd}}$ & $6.4 \pm 1.8^{\mathrm{a}}$ & $6.7 \pm 0.6^{\mathrm{cde}}$ \\
\hline $\mathrm{A} 1 \mathrm{~B} 2 \mathrm{C} 2$ & $7.0 \pm 1.5^{\mathrm{abc}}$ & $6.9 \pm 1.4^{\mathrm{abc}}$ & $7.1 \pm 1.7^{\mathrm{a}}$ & $6.9 \pm 1.5^{\mathrm{abc}}$ & $7.1 \pm 1.3^{\mathrm{a}}$ & $7.0 \pm 0.1^{\mathrm{bc}}$ \\
\hline $\mathrm{A} 2 \mathrm{~B} 1 \mathrm{C} 1$ & $7.4 \pm 1.3^{\mathrm{a}}$ & $7.9 \pm 0.9^{\mathrm{a}}$ & $7.4 \pm 1.2^{\mathrm{a}}$ & $6.4 \pm 1.7^{\mathrm{abcd}}$ & $6.9 \pm 1.8^{\mathrm{a}}$ & $6.7 \pm 0.4^{\mathrm{cde}}$ \\
\hline $\mathrm{A} 2 \mathrm{~B} 1 \mathrm{C} 2$ & $7.6 \pm 1.4^{\mathrm{a}}$ & $7.8 \pm 1.1^{\mathrm{ab}}$ & $7.5 \pm 1.1^{\mathrm{a}}$ & $7.6 \pm 1.5^{\mathrm{a}}$ & $7.4 \pm 1.2^{\mathrm{a}}$ & $7.6 \pm 0.4^{\mathrm{a}}$ \\
\hline $\mathrm{A} 2 \mathrm{~B} 2 \mathrm{C} 1$ & $7.1 \pm 2.0^{\mathrm{abc}}$ & $7.1 \pm 1.9^{\mathrm{abc}}$ & $7.1 \pm 1.8^{\mathrm{a}}$ & $6.6 \pm 1.9^{\mathrm{abcd}}$ & $7.1 \pm 1.2^{\mathrm{a}}$ & $6.9 \pm 0.2^{\mathrm{bcd}}$ \\
\hline $\mathrm{A} 2 \mathrm{~B} 2 \mathrm{C} 2$ & $6.9 \pm 1.5^{\mathrm{abc}}$ & $6.8 \pm 1.7^{\mathrm{abc}}$ & $7.2 \pm 1.5^{\mathrm{a}}$ & $6.1 \pm 1.6^{\mathrm{bcd}}$ & $7.0 \pm 1.2^{\mathrm{a}}$ & $6.6 \pm 0.4^{\mathrm{cdef}}$ \\
\hline $\mathrm{A} 3 \mathrm{~B} 1 \mathrm{C} 1$ & $6.9 \pm 1.4^{\mathrm{abc}}$ & $7.1 \pm 1.4^{\mathrm{abc}}$ & $7.1 \pm 1.6^{\mathrm{a}}$ & $6.1 \pm 1.7^{\mathrm{bcd}}$ & $7.0 \pm 1.5^{\mathrm{a}}$ & $6.8 \pm 0.4^{\mathrm{cde}}$ \\
\hline $\mathrm{A} 3 \mathrm{~B} 1 \mathrm{C} 2$ & $6.1 \pm 1.4^{\mathrm{c}}$ & $5.9 \pm 1.7^{\mathrm{c}}$ & $6.9 \pm 1.8^{\mathrm{a}}$ & $5.7 \pm 1.5^{\mathrm{cd}}$ & $6.6 \pm 1.3^{\mathrm{a}}$ & $6.1 \pm 0.4^{\mathrm{f}}$ \\
\hline A3B2C1 & $7.4 \pm 1.0^{\mathrm{a}}$ & $7.7 \pm 1.0^{\mathrm{ab}}$ & $7.1 \pm 1.7^{\mathrm{a}}$ & $7.3 \pm 1.7^{\mathrm{ab}}$ & $7.2 \pm 1.0^{\mathrm{a}}$ & $7.4 \pm 0.4^{\mathrm{ab}}$ \\
\hline A3B2C2 & $6.1 \pm 1.3^{\mathrm{c}}$ & $5.9 \pm 1.5^{\mathrm{c}}$ & $7.1 \pm 1.6^{\mathrm{a}}$ & $6.1 \pm 1.6^{\mathrm{bcd}}$ & $6.8 \pm 1.3^{\mathrm{a}}$ & $6.3 \pm 0.4^{\mathrm{ef}}$ \\
\hline control & $6.2 \pm 1.8^{\mathrm{bc}}$ & $6.1 \pm 2.0^{\mathrm{c}}$ & $6.6 \pm 2.0^{\mathrm{a}}$ & $6.4 \pm 1.9^{\mathrm{abcd}}$ & $6.6 \pm 1.7^{\mathrm{a}}$ & $6.3 \pm 0.3^{\mathrm{ef}}$ \\
\hline
\end{tabular}

*Mean \pm S.D

Means in a column not sharing the same superscript are significantly different at $\leq 0$. 
Because sample A2B1C1 and A3B2C1 had relatively higher appearance, colour, odour, taste, texture and overall acceptability comparing with the other samples. So, the storage experiment was carried out only on $\mathrm{A} 2 \mathrm{~B} 1 \mathrm{C} 1$ and $\mathrm{A} 3 \mathrm{~B} 2 \mathrm{C} 1$. As the same time, the control sample was used for comparison. Sample A2B1C1 was selected to dry by hot air/microwave to compare it with the hot air drying sample (Fig 5).

The organoleptic characteristics of husk tomato sample (A2B1C2) dried either by hot air drying or by hot air/microwave (HA/MW (A2B1C2)) were presented in Table (7).

The tabulated data indicated that husk tomato sample dried by hot air was highly acceptable than that dried by hot air/microwave with respect to appearance, taste and overall acceptability. On the other hand, no significant differences were noticed between the two samples with respect to their colour, odour and texture.

The dried sample by hot air/microwave (HA/MW (A2B1C2)) was stored at room temperature for 6 months for comparison.

Effect of pretreatments, drying methods and storage on quality of dried husk tomato

Table (8) illustrated the effect of pretreatments, drying methods and storage on quality of dried husk tomato.

The moisture content reduced from $81.49 \%$ to 9.84 , $11.08,10.06$ and $11.10 \%$ for samples $\mathrm{A} 2 \mathrm{~B} 1 \mathrm{C} 2$, A3B2C1, control and HA/MW (A2B1C2), respectively. Generally, the moisture content increased by increasing time of storage and reached to $12.29,12.7,12.53$ and $13.72 \%$ for samples $\mathrm{A} 2 \mathrm{~B} 1 \mathrm{C} 2$, $\mathrm{A} 3 \mathrm{~B} 2 \mathrm{C} 1$, control and HA/MW (A2B1C2), respectively, after six months of storage at ambient temperature. From the statistical point of view it can be revealed that the increment in moisture content of dried husk tomato for samples $\mathrm{A} 3 \mathrm{~B} 2 \mathrm{C} 1$ and $\mathrm{HA} / \mathrm{MW}$ (A2B1C2) was slightly higher than that observed in case of $\mathrm{A} 2 \mathrm{~B} 1 \mathrm{C} 2$ and the control sample. A maximum increase in moisture content of dried husk tomato during storage was found in sample HA/MW (A2B1C2) which has been dried by hot air/microwave. This sample showed significant difference with respect to its moisture content in comparison with the other samples dried by hot air and stored for six months. The increase in moisture content during storage may be due to the permeability of polyethylene pouches to gases including the atmospheric vapour inducing slight rehydration of the dried husk tomato.

The titratable acidity of husk tomato decreased significantly on a dry matter basis after drying. The reduction on acidity may be due to leaching out acids from fruit during blanching or sulphiting before drying. At zero time of storage for dried husk tomato, the percentages of reduction in titratable acidity were 30.57 , $36.60,40.04$ and $9.90 \%$ for samples A2B1C2, $\mathrm{A} 3 \mathrm{~B} 2 \mathrm{C} 1$, control and $\mathrm{HA} / \mathrm{MW}$ (A2B1C2), respectively. In all cases, the total amount of titratable acidity increased while $\mathrm{pH}$ values decreased with increasing the time of storage for dried husk tomato either dehydrated by hot air or by hot air/microwave.

From the obtained data shown in Table (8), it is clear that the drying process caused remarkable significant reduction on ascorbic acid content. The loss of ascorbic acid amounted between 70.22 to $75.15 \%$, and this decrement may be due to the pretreatments such as blanching and the relatively high temperature used during drying process. At the beginning of the storage period, ascorbic acid content was 45.45, 53.27, 44.45 and $45.30 \mathrm{mg}$ ascorbic/100 $\mathrm{g}$ sample (on dry weight basis) for samples $\mathrm{A} 2 \mathrm{~B} 1 \mathrm{C} 2, \mathrm{~A} 3 \mathrm{~B} 2 \mathrm{C} 1$, control and $\mathrm{HA} / \mathrm{MW}$ (A2B1C2), respectively. From the tabulated data, ascorbic acid content decreased by progressing the time of storage and the control sample stored for six months had the lowest ascorbic acid content, being $15.31 \mathrm{mg}$ ascorbic acid/100 g sample (on dry weight basis). From the statistical point of view and during storage, no significant differences were noticed between samples dried either by hot air or by hot air/microwave.

The percentage loss of phenolic content due to drying varied from 27.67 to $47.19 \%$. The percentage loss of phenolic content was slightly lower in case of hot air/microwave drying in comparison with the oven drying process. The total amount of phenolic content decreased with increasing the period of storage. For example, it decreased from 5.11 (zero time of storage) to $2.99 \mathrm{mg}$ gallic acid/g (on dry weight basis) after 6 months of storage of $\mathrm{A} 2 \mathrm{~B} 1 \mathrm{C} 2$ sample. The same trend had been noticed in case of the control sample. In case of $\mathrm{HA} / \mathrm{MW}$ (A2B1C2), the reduction in the total phenolic content was slightly lower than that observed in case of the oven drying and the control samples.

The results showed that, large amount of total antioxidant capacity was lost during the drying process and the percentage loss ranged between 56.89 to $67.29 \%$. After drying, the total amount of antioxidant capacity reached 9.24, 7.01, 7.08 and $7.30 \mathrm{mg}$ ascorbic acid equivalent/g sample (on dry weight basis) for sample A2B1C2, A3B2C1, control and HA/MW (A2B1C2), respectively. The reduction in total antioxidant capacity may be due to the pretreatments before drying. 
Table 7. Effect of hot air drying and hot air/microwave drying on organoleptic characteristic of dried husk tomato"

\begin{tabular}{lcc}
\hline \multirow{2}{*}{ Organoleptic characteristics } & \multicolumn{2}{c}{ Treatments } \\
\cline { 2 - 3 } & Hot air drying & Hot air/microwave drying \\
\hline Appearance & $7.4 \pm 1.6^{\mathrm{a}}$ & $6.1 \pm 1.9^{\mathrm{b}}$ \\
\hline Colour & $7.1 \pm 1.7^{\mathrm{a}}$ & $6.0 \pm 2.0^{\mathrm{a}}$ \\
\hline Odour & $7.25 \pm 2.1^{\mathrm{a}}$ & $6.25 \pm 2.0^{\mathrm{a}}$ \\
\hline Taste & $7.7 \pm 1.8^{\mathrm{a}}$ & $5.9 \pm 1.7^{\mathrm{b}}$ \\
\hline Texture & $7.0 \pm 1.8^{\mathrm{a}}$ & $6.25 \pm 2.0^{\mathrm{a}}$ \\
\hline Overall acceptability & $7.4 \pm 0.4^{\mathrm{a}}$ & $6.2 \pm 0.3^{\mathrm{b}}$ \\
\hline
\end{tabular}

* Mean \pm S.D.

Means in a column not sharing the same superscript are significantly different at $\leq 0.5$ 


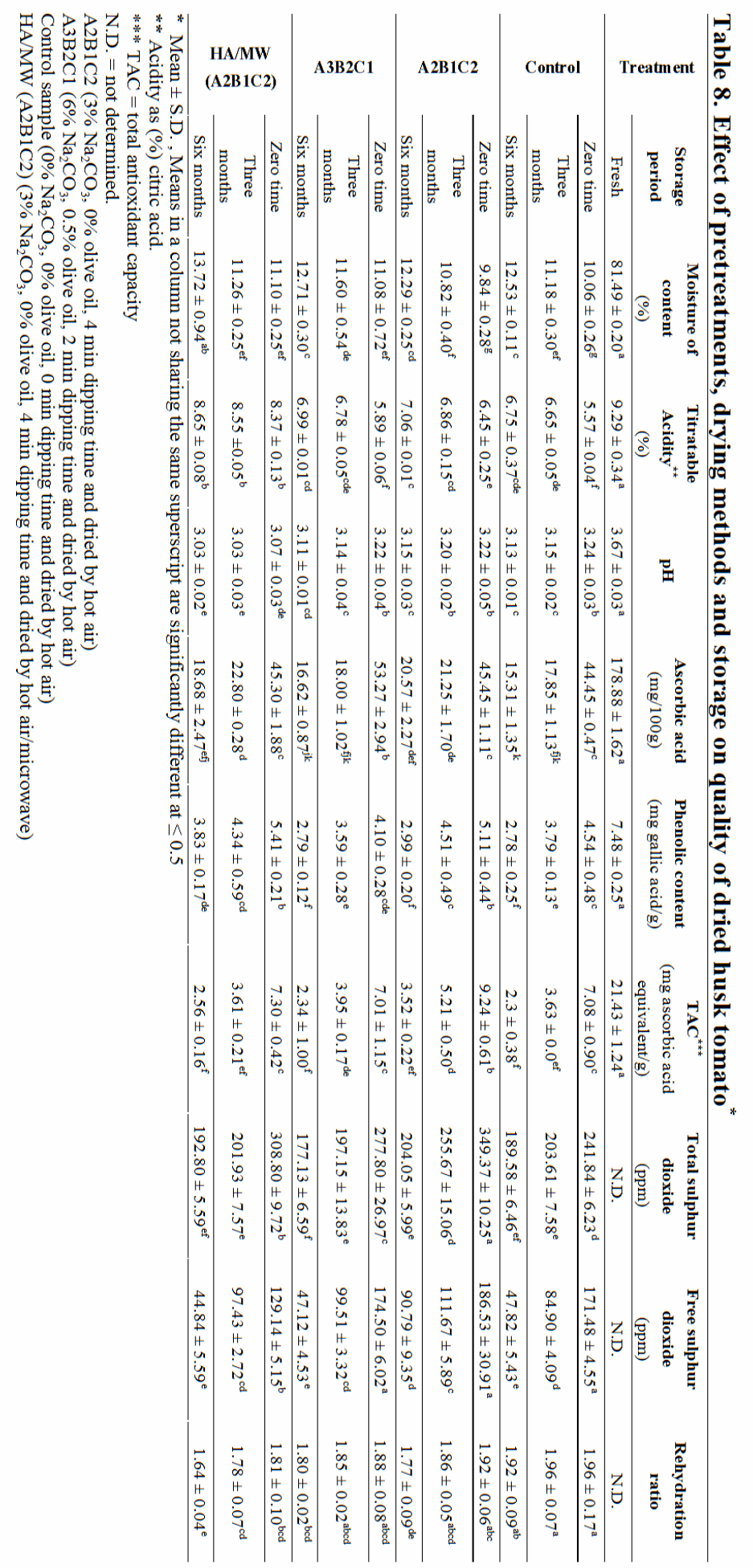



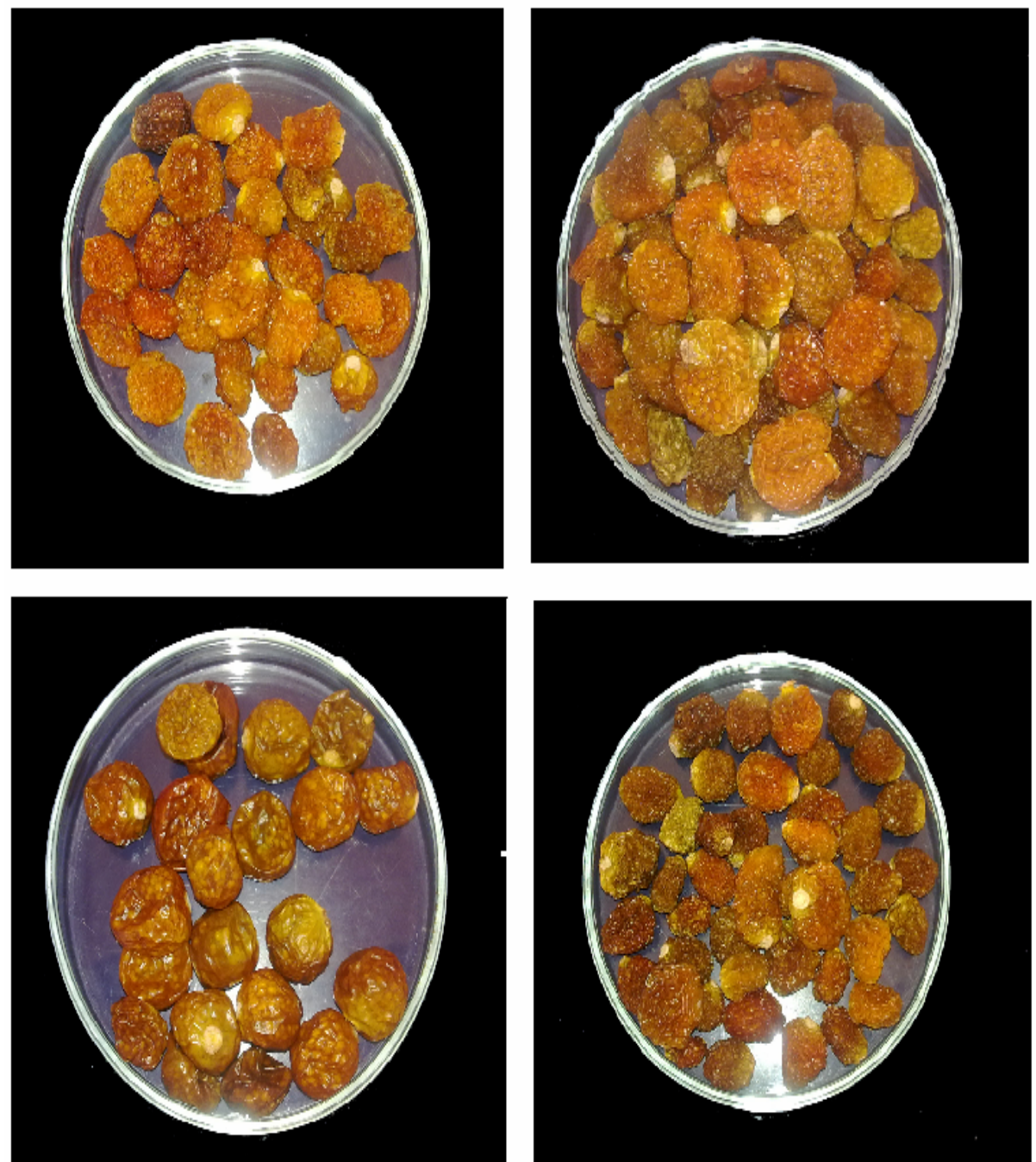

Fig. 5. Dried husk tomato samples

$\mathrm{A}=\mathrm{A} 2 \mathrm{~B} 1 \mathrm{C} 2\left(3 \% \mathrm{Na}_{2} \mathrm{CO}_{3}, 0 \%\right.$ olive oil, 4 min dipping time and dried by hot air)

$\mathrm{B}=\mathrm{A} 3 \mathrm{~B} 2 \mathrm{C} 1\left(6 \% \mathrm{Na}_{2} \mathrm{CO}_{3}, 0.5 \%\right.$ olive oil, 2 min dipping time and dried by hot air $)$

$\mathrm{C}=\mathrm{HA} / \mathrm{MW}$ (A2B1C2) (3\% $\mathrm{Na}_{2} \mathrm{CO}_{3}, 0 \%$ olive oil, 4 min dipping time and dried by hot air/microwave $)$

$\mathrm{D}=$ Control sample 
The results also revealed that the total antioxidant capacity decreased by increasing the time of storage and it reached 3.52, 2.34, 2.3 and 2.56 for $\mathrm{A} 2 \mathrm{~B} 1 \mathrm{C} 2$, A3B2C1, control and HA/MW (A2B1C2), respectively. The lowest total antioxidant capacity was observed with the control sample. No significant difference was found between the treatments after storing for six months.

From the obtained data, the residual of total $\mathrm{SO}_{2}$ after drying was 349.37, 277.80, 241.84 and 308.80 ppm and the residual of free $\mathrm{SO}_{2}$ was $186.53,174.50$, 171.48 and $129.14 \mathrm{ppm}$ for A2B1C2, A3B2C1, control and $\mathrm{HA} / \mathrm{MW}$ (A2B1C2), respectively. The percentage of total $\mathrm{SO}_{2}$ loss after three months of storage varied from 15.80 to $34.61 \%$ and then reached 21.61 to 41.59 $\%$ from initial amount of $\mathrm{SO}_{2}$ after six months (Table8), and the percentage of free $\mathrm{SO}_{2}$ loss after three months varied from 24.55 to $50.49 \%$ and then reached 51.33 to $65.28 \%$ from initial amount of $\mathrm{SO}_{2}$ after six months (Table 8). Actually, control sample had the lowest percentage losses of total $\mathrm{SO}_{2}$, while, sample A2B1C2 had the highest percentage losses of total $\mathrm{SO}_{2}$. On the other hand, A2B1C2 sample had the lowest percentage losses of free $\mathrm{SO}_{2}$, whereas, A3B2C1 sample had the highest percentage losses of free $\mathrm{SO}_{2}$.

The rehydration ratio of the dried samples of husk tomato is presented in Table (8). The rehydration ratio after drying ranged from 1.81 to 1.96 . Moreover, the control sample had the highest rehydration ratio, while, sample HA/MW (A2B1C2) had the lowest ones. Also, there is no significant difference between samples $\mathrm{A} 2 \mathrm{~B} 1 \mathrm{C} 2, \mathrm{~A} 3 \mathrm{~B} 2 \mathrm{C} 1$ and the control sample. Furthermore, the rehydration ratio decreased during storage and reached 1.77, 1.80, 1.92 and 1.64 after six months of storage for samples $\mathrm{A} 2 \mathrm{~B} 1 \mathrm{C} 2$, A3B2C1, control and HA/MW (A2B1C2), respectively. As seen from the results, HA/MW (A2B1C2) sample which has been dried by hot air/microwave had the lowest rehydration ratio either after drying or after storage for the different periods and this may be due to the effect of microwave on the physical properties of the dried tissues.

The hunter colour scale parameters, redness $\left(\mathrm{a}^{*}\right)$, yellowness $\left(b^{*}\right)$ and lightness $\left(\mathrm{L}^{*}\right)$ were used to estimate colour changes after drying process and storage of dried husk tomato. The results are given in Table (9).

Table 9. Effect of pretreatments, drying methods and storage on colour $\left(L^{*}, a^{*}, b^{*}\right.$, hue and chroma) of husk tomato*

\begin{tabular}{|c|c|c|c|c|c|c|}
\hline \multirow{2}{*}{ } & $\begin{array}{c}\begin{array}{c}\text { Storage } \\
\text { period }\end{array} \\
\end{array}$ & $\mathbf{L}^{*}$ & $a^{*}$ & $\mathbf{b}^{*}$ & Hue ${ }^{*}$ & Chroma* \\
\hline & Fresh & $49.17 \pm 1.33^{\mathrm{a}}$ & $8.25 \pm 3.57^{\mathrm{ab}}$ & $21.94 \pm 2.04^{\mathrm{a}}$ & $69.97 \pm 6.55^{\mathrm{a}}$ & $23.54 \pm 3.12^{\mathrm{a}}$ \\
\hline \multirow{3}{*}{ ن̈ } & Zero time & $42.81 \pm 1.65^{b}$ & $7.22 \pm 1.74^{\mathrm{abc}}$ & $11.78 \pm 0.91^{\mathrm{bc}}$ & $58.53 \pm 8.03^{b}$ & $13.91 \pm 0.24^{\mathrm{bc}}$ \\
\hline & Three months & $38.19 \pm 1.71^{\mathrm{d}}$ & $5.00 \pm 1.27^{\text {bcde }}$ & $5.53 \pm 1.91^{\mathrm{e}}$ & $74.42 \pm 2.96^{\mathrm{def}}$ & $7.46 \pm 0.24^{\mathrm{ef}}$ \\
\hline & Six months & $35.75 \pm 0.12^{\mathrm{ef}}$ & $1.92 \pm 0.21^{\mathrm{de}}$ & $1.73 \pm 0.10^{\mathrm{g}}$ & $42.03 \pm 4.55^{\mathrm{def}}$ & $2.59 \pm 0.05^{\mathrm{h}}$ \\
\hline \multirow{3}{*}{$\frac{\tilde{U}}{\frac{\pi}{2}}$} & Zero time & $40.67 \pm 1.22^{\mathrm{c}}$ & $9.06 \pm 2.25^{\mathrm{a}}$ & $9.97 \pm 1.62^{\mathrm{cd}}$ & $48.01 \pm 2.84^{\mathrm{def}}$ & $13.49 \pm 2.78^{\mathrm{bc}}$ \\
\hline & Three months & $36.31 \pm 0.95^{\mathrm{def}}$ & $4.80 \pm 1.26^{\text {cde }}$ & $5.03 \pm 1.53^{\mathrm{ef}}$ & $46.51 \pm 0.92^{\mathrm{def}}$ & $6.94 \pm 2.01^{\mathrm{ef}}$ \\
\hline & Six months & $35.52 \pm 0.82^{\mathrm{f}}$ & $2.93 \pm 0.17^{\mathrm{def}}$ & $3.05 \pm 0.55^{\mathrm{fg}}$ & $45.90 \pm 3.73^{\mathrm{def}}$ & $4.24 \pm 0.50^{\mathrm{fgh}}$ \\
\hline \multirow{3}{*}{$\begin{array}{l}\bar{~} \\
\text { है } \\
\text { Zै }\end{array}$} & Zero time & $42.71 \pm 1.58^{\mathrm{b}}$ & $9.01 \pm 0.88^{\mathrm{a}}$ & $13.10 \pm 1.79^{b}$ & $55.40 \pm 1.96^{\mathrm{bcd}}$ & $15.91 \pm 1.91^{b}$ \\
\hline & Three months & $37.50 \pm 0.07^{\mathrm{de}}$ & $5.32 \pm 0.06^{\mathrm{abcd}}$ & $6.21 \pm 0.05^{\mathrm{e}}$ & $49.39 \pm 0.20^{\mathrm{def}}$ & $8.17 \pm 0.07^{\mathrm{de}}$ \\
\hline & Six months & $35.66 \pm 0.71^{\mathrm{ef}}$ & $2.10 \pm 0.39^{\mathrm{de}}$ & $2.76 \pm 1.24^{\mathrm{fg}}$ & $50.58 \pm 9.14^{\text {cde }}$ & $3.49 \pm 1.20^{\mathrm{gh}}$ \\
\hline \multirow{3}{*}{ 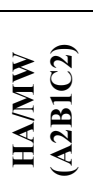 } & Zero time & $40.29 \pm 0.36^{\mathrm{c}}$ & $6.49 \pm 0.39^{\mathrm{abc}}$ & $8.62 \pm 0.10^{\mathrm{d}}$ & $53.05 \pm 1.93^{\text {bcde }}$ & $10.8 \pm 0.18^{\mathrm{cd}}$ \\
\hline & Three months & $35.53 \pm 0.82^{\mathrm{f}}$ & $4.39 \pm 0.52^{\text {cd }}$ & $4.39 \pm 0.08^{\mathrm{ef}}$ & $53.25 \pm 4.04^{\text {bcde }}$ & $6.19 \pm 0.23^{\mathrm{efg}}$ \\
\hline & Six months & $33.55 \pm 0.95^{\mathrm{g}}$ & $2.32 \pm 0.54^{\mathrm{de}}$ & $1.59 \pm 0.15^{\mathrm{g}}$ & $59.74 \pm 3.80^{\mathrm{b}}$ & $2.71 \pm 0.27^{\mathrm{h}}$ \\
\hline
\end{tabular}

\footnotetext{
*Mean \pm S.D.

Means in a column not sharing the same superscript are significantly different at $\leq 0.5$

A2B1C2 $\left(3 \% \mathrm{Na}_{2} \mathrm{CO}_{3}, 0 \%\right.$ olive oil, 4 min dipping time and dried by hot air)

A3B2C1 $\left(6 \% \mathrm{Na}_{2} \mathrm{CO}_{3}, 0.5 \%\right.$ olive oil, 2 min dipping time and dried by hot air)

Control sample $\left(0 \% \mathrm{Na}_{2} \mathrm{CO}_{3}, 0 \%\right.$ olive oil, 0 min dipping time and dried by hot air)

$\mathrm{HA} / \mathrm{MW}$ (A2B1C2) (3\% $\mathrm{Na}_{2} \mathrm{CO}_{3}, 0 \%$ olive oil, $4 \mathrm{~min}$ dipping time and dried by hot air/microwave)
} 
Husk tomato was initially light greenish-yellow with colour parameters $\mathrm{L}^{*}, \mathrm{a}^{*}$ and $\mathrm{b}^{*}$ of $49.17,8.25$ and 21.94, respectively. At the end of drying, the lightness decreased in all samples. Pretreated samples A2B1C2 and HA/MW (A2B1C2) had lower value of lightness at zero time and seemed darker in colour compared to the treated sample A3B2C1 and the control ones.

Yellowness value $\left(b^{*}\right)$ decreased after drying, while the redness value $\left(\mathrm{a}^{*}\right)$ increased in samplesA2B1C2 and $\mathrm{A} 3 \mathrm{~B} 2 \mathrm{C} 1$ and decreased in the control sample and HA/MW (A2B1C2). There were significant differences in these parameters between fresh and dried samples. This may be due to decomposition of chlorophyll and carotenoid pigments and the formation of brown pigments.

Chroma and hue angle values were calculated and the results are shown in Table (9). Chroma values decreased after drying. The chroma value indicates the degree of saturation of colour. The best colour intensity (saturation) was found in sample A3B2C1and it decreased from 23.54 to 15.91 . Also, hue angle values changed from 69.97 to $48.01,55.40,58.53$ and 53.05 for pretreated samples A2B1C2, A3B2C1, HA/MW (A2B1C2) and the control sample, respectively.

The effect of storage on colour of the dried husk tomato was also shown in Tables (9). $\mathrm{L}^{*}, \mathrm{a}^{*}, \mathrm{~b}^{*}$, chroma and hue values decreased by increasing the storage period and the colour became darker. This may be due to the reduction in total and free sulphur dioxide used during the pretreatments and thus the browning reactions' happened.

Aerobic mesophilic counts as well as yeast and molds counts were determined and presented in Tables (10). Generally, all counts were less than 25. Thus the results were reported as estimated aerobic plate count (EAPC) or estimated yeast and molds count (EYMC) < 250. These results indicated that there was no longer any microbial growth on husk tomato and no any spread of fungi or yeast.

\section{Application of dried husk tomato}

Since the drying process concentrate mostly all the components, the sour or acidic taste was increased which may be appreciated by some customers, whereas others complained about this taste. Therefore, mixing dried husk tomato with food products such as cake and coating the dried husk tomato with chocolate has been suggested to make it more acceptable. The organoleptic characteristics of cake with dried husk tomato and chocolate coated husk tomato are evaluated and presented in Table (11). From the presented data, it can be noticed that the overall acceptability of both products were high. Cake with dried husk tomato is highly accepted by the panelists and this may be due to the high sugar content in the final product. During the organoleptic test, the panelists stated some suggestions as follows:

Table 10. Effect of pretreatments, drying methods and storage on aerobic mesophilic, yeast and molds count of husk tomato

\begin{tabular}{|c|c|c|c|c|c|c|c|c|c|}
\hline \multirow{2}{*}{ Treatments } & \multirow{2}{*}{ Storage time } & \multicolumn{3}{|c|}{ Dilutions } & \multirow{2}{*}{ EAPC ${ }^{*}$} & \multicolumn{3}{|c|}{ Dilutions } & \multirow{2}{*}{ EYMC $^{* *}$} \\
\hline & & $10^{-1}$ & $10^{-2}$ & $10^{-3}$ & & $10^{-1}$ & $10^{-2}$ & $10^{-3}$ & \\
\hline \multirow{3}{*}{ Control } & Zero time & 1 & 0 & 1 & $<250$ & 0 & 0 & 0 & $<250$ \\
\hline & Three months & 3 & 2 & 2 & $<250$ & 0 & 0 & 0 & $<250$ \\
\hline & Six months & 10 & 2 & 1 & $<250$ & 0 & 0 & 0 & $<250$ \\
\hline \multirow{3}{*}{$\mathrm{A} 2 \mathrm{~B} 1 \mathrm{C} 2$} & Zero time & 2 & 1 & 2 & $<250$ & 1 & 0 & 0 & $<250$ \\
\hline & Three months & 4 & 2 & 2 & $<250$ & 1 & 0 & 0 & $<250$ \\
\hline & Six months & 8 & 1 & 0 & $<250$ & 1 & 0 & 1 & $<250$ \\
\hline \multirow{3}{*}{$\mathrm{A} 3 \mathrm{~B} 2 \mathrm{C} 1$} & Zero time & 1 & 1 & 0 & $<250$ & 8 & 0 & 0 & $<250$ \\
\hline & Three months & 3 & 3 & 2 & $<250$ & 1 & 0 & 0 & $<250$ \\
\hline & Six months & 4 & 3 & 2 & $<250$ & 0 & 0 & 0 & $<250$ \\
\hline \multirow{3}{*}{$\begin{array}{l}\mathrm{HA} / \mathrm{MW} \\
\text { (A2B1C2) }\end{array}$} & Zero time & 1 & 1 & 0 & $<250$ & 0 & 0 & 0 & $<250$ \\
\hline & Three months & 1 & 4 & 2 & $<250$ & 0 & 0 & 0 & $<250$ \\
\hline & Six months & 3 & 3 & 1 & $<250$ & 0 & 0 & 0 & $<250$ \\
\hline
\end{tabular}

* EAPC estimated aerobic plate count

** EYMC estimated yeast and molds count

A2B1C2 (3\% $\mathrm{Na}_{2} \mathrm{CO}_{3}, 0 \%$ olive oil, 4 min dipping time and dried by hot air)

A3B2C1 $\left(6 \% \mathrm{Na}_{2} \mathrm{CO}_{3}, 0.5 \%\right.$ olive oil, 2 min dipping time and dried by hot air)

Control sample $\left(0 \% \mathrm{Na}_{2} \mathrm{CO}_{3}, 0 \%\right.$ olive oil, 0 min dipping time and dried by hot air)

$\mathrm{HA} / \mathrm{MW}$ (A2B1C2) (3\% $\mathrm{Na}_{2} \mathrm{CO}_{3}, 0 \%$ olive oil, 4 min dipping time and dried by hot air/microwave) 
Table 11. The organoleptic characteristics of cake with dried husk tomato and coated chocolate husk tomato*

\begin{tabular}{lcc}
\hline \multicolumn{1}{c}{ Parameters $^{*}$} & cake with dried husk tomato & coated chocolate husk tomato \\
\hline Appearance & $8.0 \pm 1.3$ & $7.2 \pm 1.6$ \\
\hline Colour & $8.4 \pm 1.0$ & $7.7 \pm 1.2$ \\
\hline Odour & $8.2 \pm 1.3$ & $8.2 \pm 1.3$ \\
\hline Taste & $7.9 \pm 1.2$ & $7.5 \pm 1.3$ \\
\hline Texture & $8.0 \pm 1.2$ & $7.6 \pm 1.2$ \\
\hline Overall acceptability & $8.1 \pm 1.3$ & $7.6 \pm 1.4$ \\
\hline
\end{tabular}

* Mean \pm S.D.

- Cutting dried husk tomato to small pieces before immerge it in cake to increase uniformity and improve the appearance.

- Increase the layers of chocolate by dipping dried husk tomato in melted chocolate several times to enhance the appearance and improve the taste.

- Mixing butter and milk during melting chocolate before immersing dried husk tomato through it, to give it polish appear and colour and enhance the nutrition value and improve the taste.

As a conclusion, combining hot air with microwave drying reduced the drying time by about $35 \%$. On the other hand, the organoleptic properties of cake containing dried husk tomato and husk tomato coated with chocolate were accepted by the panelists with some suggestions for further studies.

\section{REFERENCES}

Abd El-Ghaffar, E.A. 2009. Astudy on kinetics of drying process of some fruits and vegetables. Ph.D. Thesis, Food Sci. Dept. Fac. of Agric., Ain Shams Univ., Egypt.

Abd El-Lahot, M.S.R. 2010. Effect of roasting and storage processes on chemical and physical properties of coffee. M.Sc. Thesis, food science and technol. Fac. of Agric., Alex. Univ., Egypt.

Abou-Gharbia, H.A. \& Abou-Tour, E.M. 2001. Properties and processing of husk tomato (Physalis pruinosa L.). Minufiya J. Agric. Res., 26: 761-781.

Alibas, I. (2007). Microwave, air and combined microwaveair drying parameters of pumpkin slieces LWT-Food Sci. and Technol., 40: 1445-1451.

Amer, B.M. 1999. Determination of drying rate of fruits as a function of the affecting factors under conditions suiting solar drying. M.Sc. Thesis, Agricultural Eng. Dept., Faculty of Agric., Cairo Univ., Egypt.

Association of Official Analytical Chemists (AOAC) 2003. Official methods of analytical .Helrich, K. $17^{\text {th }}$ ed. Virginia, USA.

Association of Official Analytical Chemists (AOAC) 2000. Official methods of analytical. $17^{\text {th }}$ ed. Gaitherburg: Maryland, USA.
Babalis, S.J. \& Belessiotis, V.G. 2004. Influence of the drying conditions on the drying constants and moisture diffusivity during the thin-layer drying of figs. J. food Eng., 65 : 449-458.

Bakry, N.A. 2003. The chemical composition and processing of goldenberry (Physalis peruviana) grown in Egypt. M. Sc. Thesis, Public Health science(food analysis). High Institute of Public Health. Alex. Univ., Egypt.

Barbosa-Canovas, G.V. \& Vega-Mercado, H. 1996. Other Methods of Dehydration of Foods and Packaging Aspects. In: Barbosa- Canovas, G.V. and Vega-Mercado, H. (Eds.), Dehydration of Foods. New York: Chapman \& Hall : 289-320.

Bekheit, A.A.A. 2002. Production and evaluation of Egyptian date sheets and pastes. M. Sc. Thesis, Food Sci. and Tech. Dept. Fac. of Agric., Cairo Univ., Egypt.

Bondaruk, J., Markowski, M. \& Blaszczak, W. 2007. Effect of drying conditions on the quality of vacuum-microwave dried potato cubes. J. Food Eng., 81: 306-312.

Caliskan, O. \& Polat, A.A. 2011. Phytochemical and antioxidant properties of selected fig (Ficus carica L.) accessions from the eastern Mediterranean region of Turkey. Scientia Hort., 128 : 473-478.

Cantwell, M., Flores-Minutti, J. \& Trejo-Gonzalez, A. 1992. Developmental changes and postharvest physiology of tomatillo fruits (Physalis ixocarpa Brot.). Scientia Hort., 50: 59-70.

Dean, A. \& Voss, D. 2005. Design and Analysis of Experiments Springer - Verlag, New York.

El-Abasy, A.E.M. 2011. Formulation and evaluation of some functional juice mixes and bakery products. M. Sc. Thesis, food science and technol. Fac. of Agric., Alex. Univ., Egypt.

Fogliano, V., Verde, V., Randazzo, G. \& Ritieni, A. 1999. Method for measuring antioxidant activity and its application to monitoring the antioxidant capacity of wines. J. Agric. Food Chem., 47: 1035-1040.

Gomez,M., Ruiz, E. \& Oliete, B. 2011. Effect of batter freezing conditions and resting time on cake quality. LWT - Food Sci. and Technol., 44: 911-916.

Gouda, M.S.M. 1974. Chemical and technological studies on imported varieties planted in Egypt. M. Sc. Thesis, Food Sci. and Tech. Dept. Fac. of Agric., Alex. Univ., Egypt. 
Hamed, E.Y. 2008. Drying grapes using microwave. M. Sc. Thesis, Agricultural engineering. Fac. of Agric., Alex. Univ., Egypt.

Konyaloglu, S., Saglam, H. \& Kvcak, B. 2005. a-Tocopherol, flavonoid, and phenol contents and antioxidant activity of ficus carica leaves. Pharmaceutical Biol., 43: 683-686.

Krokida, M.K. \& Marinos-Koouris, D. 2003. Rehydration kinetics of dehydrated products, J. Food Eng., $57: 1-7$.

Maskan, M. 2000. Microwave/air and microwave finish drying of banana, J. Food Eng., 44: 71-78.

McDonald S., Prenzler, P.D., Antolovich M. \& Robards K. 2001: Phenolic content and antioxidant activity of olive extract. Food Chem. 73: 73-84.

Morton, J.F. 1987. Cape Gooseberry. In: Julia, F., Morton, J. and Miami, F.L. (Eds.), Fruit of warm climates. Sanfransisco: Freeman Co, :430-434.

Mujumdar, A.S. \& Menon, A.S. 1995. Drying of solids: principles, classification, and selection of dryers. In: Mujumdar, A.S.(Eds.), Handbook of Industrial Drying. Marcel-Dekker Inc., New York, USA, 1: 1-39.

Oztekin, S., Zorlugenc, B. \& Zorlugenc, F.K. 2006. Effects of ozone treatment on micro flora of dried figs. J. Food Eng., 75: 396-399.
Polat, A.A. \& Caliskan, O. 2008. Fruit characteristics of table fig (Ficus carica) cultivars in subtropical climate conditions of the Mediterranean region. New Zealand J. Crop and Hort. Sci., 36 :107-115.

Popenoe, H. 1989. Lost Crops of The Incas. Washington DC. National Academy Press.

Raghavan, G.S.V., Rennie, T.J., Sunkja, P.S. , Orsat, V. , Phaphuangwittayakul, W. \& Terdtoon, P. 2005. Overview of new techniques for drying biological materials with emphasis on energy aspects. Braz. J. Chem. Eng., 22 : ????-????

Ranganna, S. 1995. Handbook of Analysis and Quality Control for Fruit and Vegetable Products. $2^{\text {nd }}$ ed. Tata McGraw-Hill Publishing Company Limited. New Delhi.

Rubatzky, V. and Yamaguchi, M. 1997. World Vegetables. $2^{\text {nd }}$ ed. New York: Alan R liss INC.

Schiffmann, R.F. 1995. Microwave and Dielectric Drying. In: Mujumdar, A.S. (Eds.), Handbook of Industrial Drying. New York, USA, :345-372.

Tosun, N. and Delen, N. 1998. Minimising of contaminaton of aflatoxigenic fungi and subsequent aflatoxin development in fig orchards by fungicides. Acta Hort., 480: 193-197.

Vietmeyer, N.D. 1986. Lesser-known plants of potential use in agriculture and forestry. Science, $232: 1379-1384$.

Willis, J.C. 1966. A Dictionary of Flowering Plants and Ferns. Cambridge, UK: Cambridge Univ Pess. 


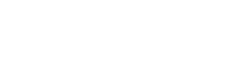

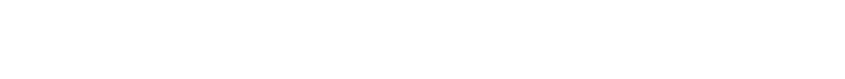

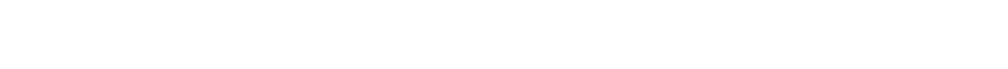

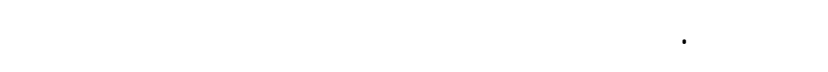

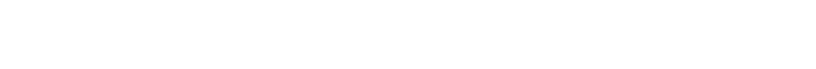

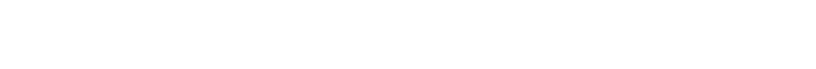

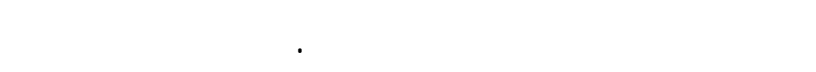

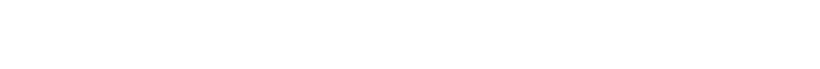

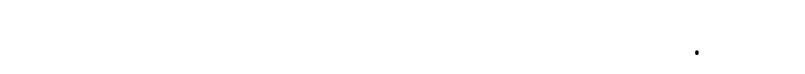

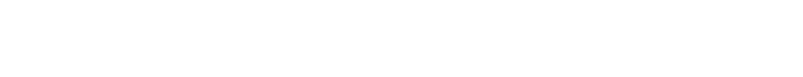

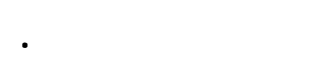

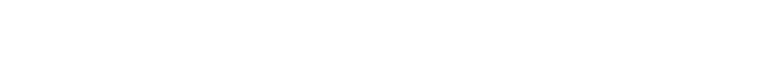

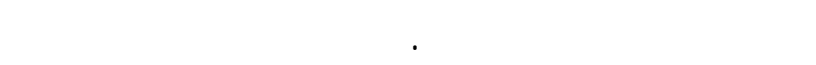

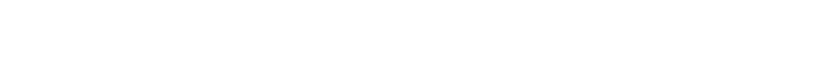

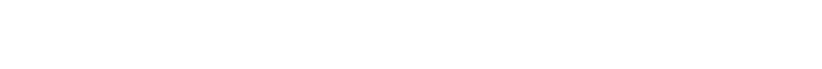

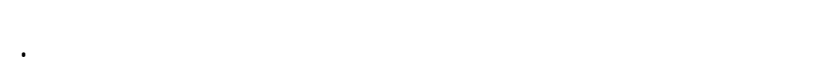

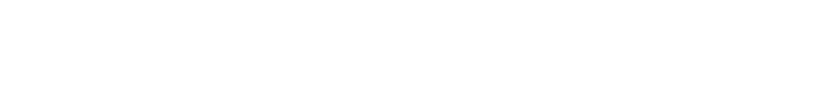

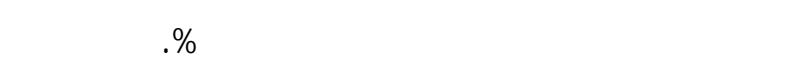

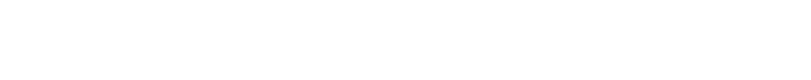

